\title{
Botanical nature writing: an ecocritical analysis
}

\author{
Kadri Tüür ${ }^{\mathrm{a} \bowtie}$ and Triin Reitalu ${ }^{\mathrm{b}}$ \\ a Department of Semiotics, Institute of Philosophy and Semiotics, University of Tartu, Jakobi 2, \\ 51014 Tartu, Estonia \\ ${ }^{\mathrm{b}}$ Institute of Geology, Tallinn University of Technology, Ehitajate tee 5, 19086 Tallinn, Estonia \\ $\bowtie$ Corresponding author, tyyr@ut.ee
}

Received 25 January 2011, revised 11 June 2011, accepted 26 June 2011

\begin{abstract}
We present an ecocritical analysis of Haide-Ene Rebassoo's book of nature writing Botaanilisi kilde 17 Hiiumaa suvest [Botanical Fragments from 17 Summers in Hiiumaa]. The dynamic tripartite model of nature writing is applied on the source material for advancing ecocritical theory, as well as for demonstrating the relevance of ecocriticism in the study of previously underconceptualized texts often considered popular science. On the basis of the analysis, it is concluded that our source text features scientific, belletristic, and pragmatic dimensions of nature writing, with the main emphasis on botanical scientific knowledge.
\end{abstract}

Key words: ecocriticism, botany, nature writing, nature protection.

\section{INTRODUCTION}

The background of the present article lies in the American tradition of ecocritical literary studies and in a concept central to it, nature writing. Our purpose is to detect the tradition of nature writing in Estonia and to analyse its characteristic traits on the example of a botany-focused book. In introducing the notion of nature writing (Finch \& Elder, 2002) and applying ecocritical reading (Glotfelty $\&$ Fromm, 1996) on an exemplary text (Rebassoo, 1975a), we want to test the benefits of literary analysis for texts that have been regarded as popular science in Estonian reception and left without much critical response. There is a whole array of books on natural history that in some regard conform too little to the rules of popular science, but cannot be considered fiction either. The problem is that such texts have been written for decades, but they have not received much critical attention or feedback. The lack of conceptual tools is definitely one reason for this situation.

Ecocritical interest in nature writing provides a context for re-actualizing a wide range of previously under-conceptualized publications. As a recently developed approach in literary theory that focuses on human-environment relationships (Buell, 1995; Love, 2003; Murphy, 2009), ecocriticism has taken nature writing as one of the central types of literature studied with its methods. In the Anglo-American tradition, the notions such as wilderness, experience of sublime, 
solitude, pastoral, and apocalypse have been central for the scholars analysing such texts (Garrard, 2009). One of the distinctive traits of the Estonian tradition of nature writing is a strong scientific background of its authors (Tüür \& Maran, 2005). Scientific names, data, and explanations are routinely provided as comments to the immediate observations of natural phenomena. At the same time, such texts cannot be approached as academic papers as the writer's subjective persona is ever present in them. The solution we are offering in the present article is to consider such texts as nature writing. The dynamic model of nature writing is introduced and applied, demonstrating some possibilities of ecocritical analysis.

\section{MATERIAL AND METHODS}

\section{Source material}

The source material for the present study is a book based on botanical fieldwork notes that resembles a diary rather than a research text.

The author Haide-Ene Rebassoo (b. 1935) is an Estonian botanist who has published extensively on Estonian plants, plant communities, their distribution and protection; she has written chapters for encyclopaedic collections and accounts of plants for a wider public (for her bibliography, see Kukk, 1999). The present article focuses on her book titled Botaanilisi kilde 17 Hiiumaa suvest [Botanical Fragments from 17 Summers in Hiiumaa] (further referred to as BF), published in 1975. Unlike the majority of the books issued during the Soviet period, this one does not have an annotation on its impressum page. It is merely indicated that 10000 copies of the book were printed. No reviews of the book appeared in periodicals.

As the title of the book suggests, flora and botanical knowledge are the focus of the text. The time span specified in the title is 17 summers. Each year's accounts are limited to summer, or at least to the vegetation period, as this is the most suitable time for botanical explorations. The setting is specified as the island of Hiiumaa, North-West Estonia. At the beginning of the book, a hand-drawn map of Hiiumaa is presented (Fig. 1), showing the natural features of the island (rivers, swamps, islets) and the approximate locations of the settlements mentioned in the text. The elements of the natural environment are brought to the fore; no roads are marked on the map.

BF has three inserted sections of black and white plant photographs, each section containing 41 to 44 photos, 129 in total. The lyrical captions accompanying the relatively high-quality illustrations indicate that their intended function was not only documenting the plants, but also conveying the beauty of the nature. Fieldwork notebooks served as the main source material for the text. The composition as well as the contents of the book were prepared and proposed to the publisher by the author herself. No major alterations were made in the manuscript during the editing process (Mall Johanson, editor of BF, pers. comm. 02.11.2010). 


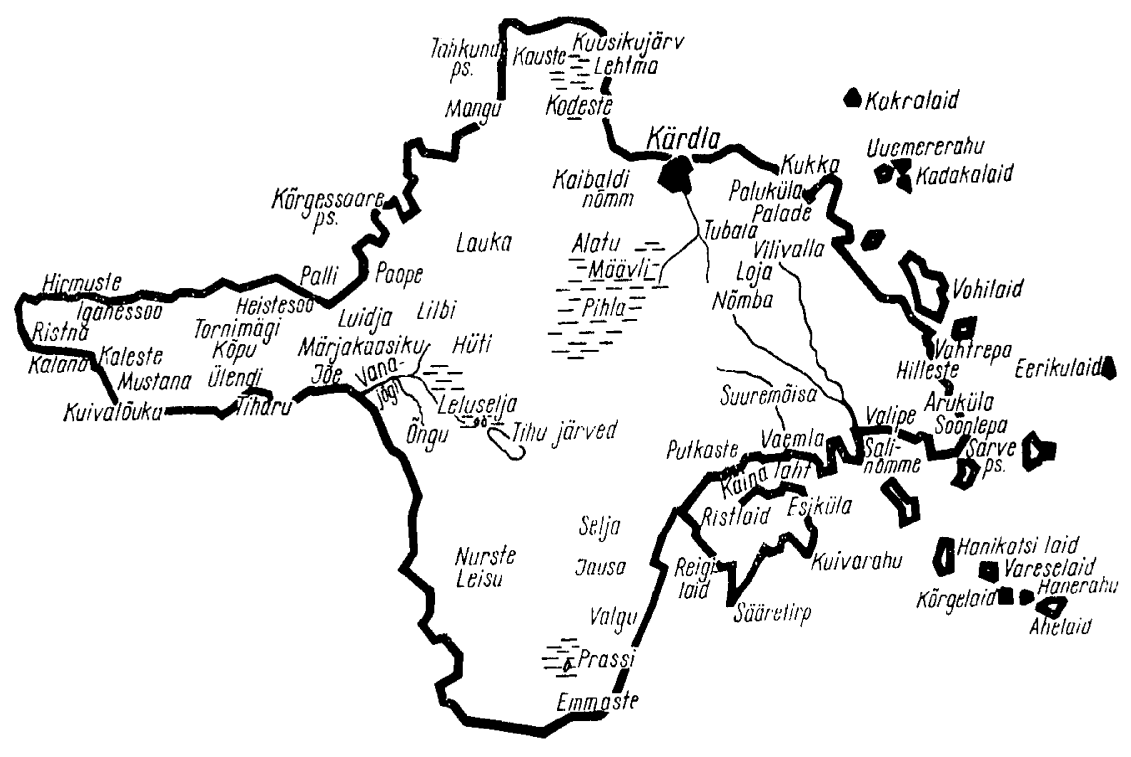

Fig. 1. The map of Hiiumaa from Rebassoo, 1975.

For the most part, the text describes encounters with various plants of Hiiumaa, both ordinary and rare, whether rare because of numbers or a specific quality. Contacts with local cultural history and local community are scarcely referred to. However, the book contains a social dimension in the sense that it carries and forwards the pathos of nature conservation of its time. All these aspects of the book will be discussed in more detail, drawing methodological support from an ecocritical approach, set against scientific (botanical) background.

\section{Methods}

In the present article, we examine $\mathrm{BF}$ as nature writing, which is a concept stemming from ecocriticism and developed further in concordance with the ecosemiotic approach. Ecocriticism is quite simply explained as 'the study of the relationship between literature and the physical environment' (Glotfelty \& Fromm, 1996). The ISLE reader, a more recent anthology surveying the development of ecocritical thought up to the 21 st century, explains ecocriticism as 'concerned with the environmental implications of literary texts' (Branch \& Slovic, 2003), suggesting that any literary work can be read from the 'green' perspective and that analytical frameworks developed in other disciplines can be incorporated into an ecocritical reading.

Ecosemiotics is a recent development in the study of semiotic relations between human culture and living nature (Nöth, 1996; Kull, 1998). It studies the meaning 
processes involved in nature experience (Maran, 2010). Combination of ecocritical methods with ecosemiotic ones enables to generalize the models formed on the basis of empirical study of nature writing.

Nature writing has formed the cornerstone and primary source material for ecocriticism since its establishment as a distinctive field of literary study. The texts considered as nature writing are first-person narrative essays (i.e. nonfiction) that, 'while scientifically informed, are also marked by a personal voice and a concern for literary values' (Finch \& Elder, 2002). The texts of nature writing, unlike fiction, are not an end in themselves, but serve as means for persuading the reader to visit the same places and see the same species, in order to gain real-life experience similar to that of the author of the text.

\section{Dynamic model of nature writing}

Nature writing as a certain type of literary text mediates nature and culture, bringing the processes in nature into the realm of human written culture. In nature writing, the culture-nature interaction is modelled, and its analysis can reveal certain ideological aspects of their cultural context. Nature writing provides invaluable examples of how we grasp, understand, and interpret nature by means unique to human species, i.e. by highly abstract language.

Drawing from the definitions and descriptions provided in ecocriticism (Buell, 1995; Lyon, 1996; Finch \& Elder, 2002), three major dimensions define a text as 'nature writing':

(1) The text is based on immediate, scientifically apt observation of some particular location, species, or process in nature.

(2) The experience is formulated as an essayistic text, created with an artistic ambition; often aesthetic aspects of nature are foregrounded.

(3) The pragmatic aims of nature writing are to evoke interest towards nature in the reader and to encourage establishing immediate connections with nature, therefore such texts contain direct references to the objects outside textual reality (i.e. in the natural world).

The first dimension can be associated with the tradition of scientific writing, and its particular manifestations include, for example, indications of exact dates, locations, scientific names of species, and other scientific data. The second dimension is related to belletristic writing, e.g. bringing along autobiographical elements, metaphorical expression, abundance of epithets, and intertextual references that would commonly be avoided in a scientific paper. The third dimension is related to texts as pragmatic commodities or aids for achieving some practical goal such as sharing information on the practical usage of natural objects, instructions on travel routes, wild animal behaviour, maps, photos, and schemes.

The three-fold influences from the described textual fields can be depicted as overlapping circles (Fig. 2). According to this schema, nature writing is formed in the intersection of three marginally overlapping types of texts: scientific texts, belletristic texts, and pragmatic texts (Tüür, 2007). 


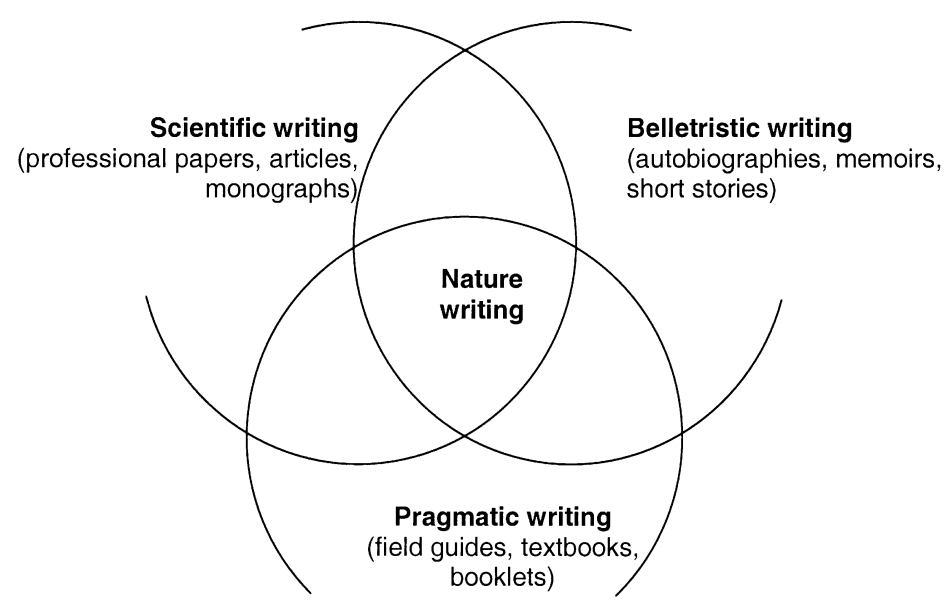

Fig. 2. A dynamic model of nature writing. The three general component fields and the overlapping area on their margins, which constitute the realm of nature writing.

\section{BF AS NATURE WRITING}

According to the model of nature writing, a text conforming to such a definition combines aspects of three types of texts, namely, scientific, belletristic, and pragmatic texts. In the following discussion, BR is examined to determine the extent to which it displays each of these characteristics.

\section{Scientific dimension}

The first, scientific dimension of nature writing is most obvious in BF, as the subject matter of the book is plants, regarded from a botanical-scientific viewpoint. Other topics are rarely touched upon. Chronological analysis reveals that the author's activities beyond professional scope have probably even been systematically omitted from the book. In some instances, an observation of birds is recorded, but they appear as a function of the plants, namely, as their travelling vehicles. Therefore it is an exceptionally focused piece of nature writing. Setting such a scope for a book has both advantages and disadvantages, as it requires at least some botanical competence (or, some shared passion) from the reader. The aim of an environmental 'thick description', according to Buell (1995), is to give proof of the quality of nature writing to render more nuances in the environment than the reader alone would be able to notice. The detailed attention may be selective, though, and this appears to be quite true in the case of BF.

The author does not restrict herself to only botanical nomenclature - she sometimes tacks adjectives onto some of the plant names, making it difficult for the average reader to distinguish her words from the scientific name. Such 'special' 
plants include, for example, poisonous (adjective) Daphne mezereum, tender (adjective) Carex limosa, pink-blossomed (adjective) Glaux maritima, and Astralus danicus - a legume with tight purplish blue inflorescences.

The author's focus throughout the book is on single species rather than plant communities. In some cases, a strong inclination to typologization occurs. Towards the beginning of the book, plants are presented in extensive lists, containing up to 20 plant names in one sentence (see, for example, BF: 34). As the flora becomes more familiar to the writer over the summers, lists are gradually replaced by longer descriptions of individual species. In the plant descriptions, strictly scientific vocabulary is used (e.g. spikelet, nut, stipules, whorl, obovate capsule, halophilous, opposite epetiolate ovate leaves, etc.). As a rule, information about the geographical distribution of the species is provided.

The collection and observation of rarities seem to be among Rebassoo's favourite botanical activities. Such interest has strong nature protectionist implications. The monitoring of rare species in Hiiumaa is carried out with consistency during the years described in BF. Rebassoo searches for and pays repeated visits to Hiiumaa's ivy specimens and yew grooves. In the text she compares the vegetation parameters and follows what could be termed 'the time of plants' - the sprouting, vegetation growth dynamics, and disappearance of certain specimens over time. She is fully aware that a plant's time scale differs from that of the humans and only long-term observation allows us to understand vegetation dynamics.

In her $\mathrm{PhD}$ thesis completed parallel to making field notes for BF, Rebassoo states, 'The fieldwork methodology has predominantly relied on excursions. The routes were chosen randomly during the first years (1956-1958); later (1959-1965) the routes were chosen so that finding places of certain plant species were (re-)visited; also the questions concerning the genesis of flora and other plant geographical issues were studied by examining a certain limited territory' (Rebassoo, 1967). Random hikes were gradually replaced by repeated visits to certain locations and observations of particular plant specimens, especially the rare ones.

It is especially interesting to observe how the author's scientific nature conservationist ideas explicitly relate the text with the broader social context of its time, and also guide the author's understanding of particular landscapes. The end of the 1950s was the time of re-establishing state-organized nature protection in Estonia (Eilart, 1976). Parallel to her scientific fieldwork, Rebassoo was actively engaged in these activities, helping to find, describe, and evaluate the objects that would be worth protection. Her approach is very much object-, not processcentred, illustrating well the understanding of the notion of 'protection' of that time. In some other writings, she expresses a somewhat wider understanding of nature protection. In an article about nature protection on small islets (Rebassoo, 1975b), she starts out with an extensive list of plants that need protection as relics or species growing at their distributional border, but concludes that plants must always be protected together with their habitat. For this purpose, she suggests that small islets should be taken under protection in their entirety. Although she provides a schema on the natural as well as anthropogenic factors influencing the 
development of flora on small islets in the article, her protection proposal does not include any human intervention.

In the semi-natural communities Rebassoo tends to reconstruct an earlier community type of broad-leaved forest in her text, assigning it higher conservation value over the wooded meadows and pasturelands. She regards the extensive herding of cows on the fragile coastal plant ecosystems as a major threat. It is highly probable that over-grazing was a problem on some of the coastal meadows and islet pasturelands in the 1960s-1970s, as Rebassoo eloquently describes in $\mathrm{BF}$, but the importance of grazing for maintaining open landscapes must not be underestimated. Thus, her pathos is in sharp contrast with the contemporary understanding of the semi-natural communities as highly valuable and of the herding as the key component of nature conservation (see Lotman \& Lepik, 2004).

In Rebassoo's writings, a more general trend in Estonian nature conservationist ideas becomes visible: a gradual shift from the idea of protecting single objects or (rare) specimens to the protection of habitats. In that regard, BF is an important document about the development of the nature conservationist ideas in Estonia, as Rebassoo expresses them in her text as personally comprehended and emotionally relevant part of one's experience of nature.

\section{Belletristic dimension}

The author's voice in the text, expressing her personal ideas and occasionally wording the positive emotions associated with fieldwork, grows stronger as time goes by. Personal contact with the environment and metaphorical usage of words characterize this dimension.

The emotional epithets attached to the described species show the author's attitude to the plant. In addition to the epithets, the author's emotional attitude towards the flora is conveyed in a less subtle way in numerous interjections in the text, such as 'Surprise!' (BF: 69, 80, 81), 'It can not be!' (BF: 77), and 'What a botanical sensation!' (BF: 102). These allude to the author's strong wish to share her joy about the encounters with plants with her reader not only on the referential, but also on the emotional level. This indeed is something that would be left out of scientific research papers, but nature writing, as well as unpublished field notes, allow a scientist to express her feelings in a less restricted way, thus giving a more personal taint to the predominantly scientific activities.

The young and enthusiastic student of botany depicts herself within the text: 'Carrying a backpack and a plant frame I step into a local bus that takes me to the places where I wish to go. I am off to a two months long botanical practicum in Hiiumaa, with the goals of getting thoroughly acquainted with the flora of Hiiumaa, collecting its samples, and gathering material for my BSc thesis.' (BF: 9). Further in the text, she describes measuring distances with steps, using a compass, crossing various types of landscape while following direct transect lines on a diverse landscape, revealing her immediate, bodily presence in the natural environment. The author makes remarks about her wet feet, scratching shrubs, 
sinking silt, beaming sun; she also recalls her mouth-watering encounters with Hiiumaa's wild berries, and occasionally gladly notes the absence of mosquitoes. The reader can have no doubt that the author is present in the landscape with all of her senses. This is indeed a dimension that is omitted in scientific papers, but the one that makes the activities of a botanist closer to an average reader.

The usage of the verb 'travel' develops into a wider metaphor in the text. The image of travelling plants is made literally pictorial in the following passage: 'An ancient road from Sarve to Heltermaa harbour passes this site. It must be that Anagallis arvensis has grabbed from the horse-drawn cart with all its teeth and claws, and travelled from Sarve to the coast of the sea this way' (BF: 42). Another means of fast transportation for plant seeds, also referred to as 'travelling' in BF, is the flocks of birds of passage that carry various edible plant seeds onto the sea shore and distant small islets in the sea in their bellies.

The metaphor of travelling suits well Rebassoo's own dynamics of activities. She is always on the move, ruthlessly passing difficult landscapes, searching for plants to be monitored, hiking from one fieldwork site to another. Only towards the very end of the book a couple of passages are given when she 'steals the moment', lying down on a moss-covered stone in the middle of a forest, or stopping to collect and eat strawberries (BF: 100-102, 127-128). Each occasion of peace is followed by a certain shame and a slight regret about the moments that slip away fast. This slower pace indicates the author's growing familiarity with the place. Peculiarly enough, it does not mean familiarity with the people living in the place but with the plants.

The author's persona determines the structure of the book to a great degree for example, the records and omissions in the chronological line of the diary. The rhapsodic oscillations between places at the beginning of the book calm down towards the end, making the text easier to follow. This dynamics could be explained with the growing familiarity of the author with her fieldwork areas: at the beginning of her trips, she feels like a stranger in Hiiumaa, but as her knowledge of the local flora grows and her movement trajectories get more purpose-driven, she allows for more personal comments. Her confidence as a person grows on a professional as well as on the everyday plane. Thus we can see the experience of place conditioning the personal becoming. Nature shapes the author, as well as the dynamics of the text written about her experience of nature.

\section{Pragmatic dimension}

Nature writing often includes educational or practical information that is aimed at fulfilling the readers' practical needs that may possibly arise: how to recognize a place or a species, how to find one's way in the particular natural environment, etc.

In $\mathrm{BF}$, illustrations and diary-like structure of the text support the pragmatic dimension. The map (see Fig. 1) provides a tool for the reader to become oriented in the textualized landscape. The photographs attempt to create an intersemiotic whole with textual and visual components supporting each other in the creation of 
a new level of meaning (for an analysis of intersemiosis in nature writing, see Tüür, 2004). It is interesting to note that the majority of the photos are plant close-ups, not general landscape views, and the same tendency is prevailing in the text: the descriptions of nature predominantly concentrate on single plants and their details; landscapes, locations, and trajectories are scarcely described. Two possible explanations could be given for such practice: first, it reflected the author's interest in the micro-level of landscapes (the plants); and second, it was safer not to provide detailed information about roads or give panoramic views of the island landscapes that were considered sensitive military information by the then regime because of the presence of military installations on the island.

The dynamics of the general time scale covered in the book, as well as the chronological line of Rebassoo's visits to Hiiumaa, is rather fragmentary (as already suggested in the title). Most visits during the 17 years described were made in June and the first half of July (Fig. 3). Towards the beginning of the book, the covered time periods are longer and concentrated; then the described time periods shrink to merely a couple of days per year, and towards the end of the book the time span is prolonged to incorporate the months of May and September. Such a timeline suggests concordance with the dynamics of the writer's personal relationships with her study area. During her earlier trips, she is a student with a certain task to be accomplished within a certain time frame. As her emotional contacts with the place grow stronger, she starts to represent only the brightest selected moments of her research activities in her 'plant diary'. Diary form convinces the reader of nature writing of the author's incessant spatial and temporal involvement with the described environment (Slovic, 1996). The author's botanical visits gradually increase in time and decrease in spatial amplitude. The described periods of stay in Hiiumaa are prolonged, whereas the number of different places visited during the described stays decreases. The book provides sufficient

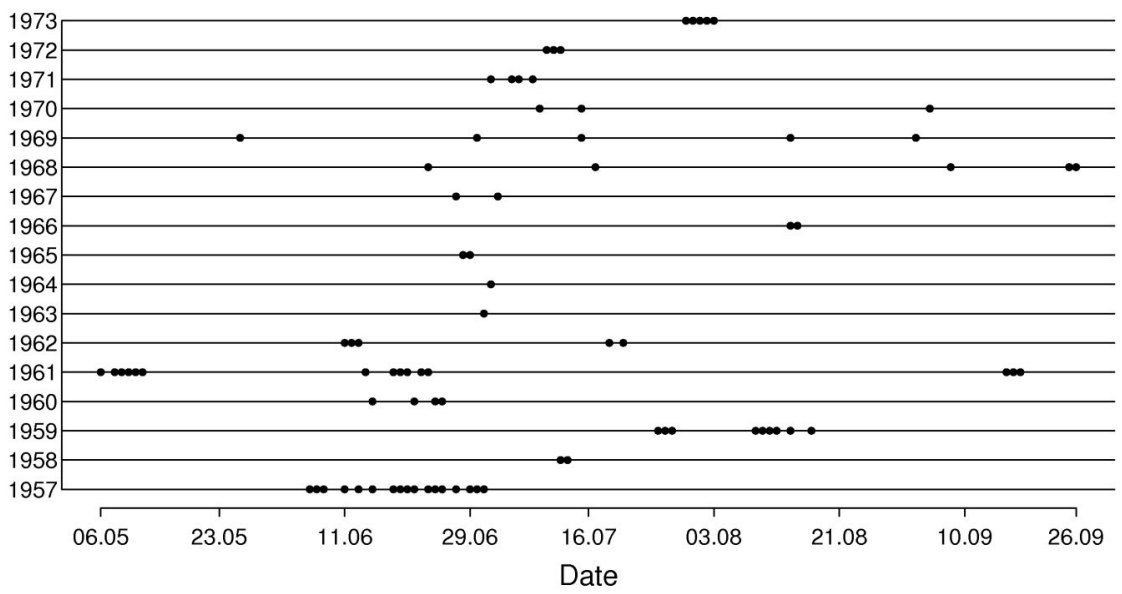

Fig. 3. The timeline in Rebassoo, 1975. Each date featuring an entry in the text is marked with a dot. 
information to a reader wishing to follow the footsteps of the author. Much has altered in the plant communities and human communities, as well as in the attitudes and priorities concerning nature protection, but one of the virtues of nature writing is that it is able to demonstrate the historical dimension of natural environments.

\section{CONCLUSION}

The theoretical model for analysing nature writing used in the present study was developed mainly in the framework of ecocriticism, the critical study of environment as it appears in written narratives. Nature writing is a type of literature that is formed on the margins of three broader categories of written texts, namely scientific writing, belletristic writing, and pragmatic writing. As such, it has only recently been conceptualized as a distinctive type of texts deserving critical as well as scientific attention. The book Botaanilisi kilde 17 Hiiumaa suvest [Botanical Fragments from 17 Summers in Hiiumaa] by HaideEne Rebassoo, which has typically been seen as a popular science work, proves to be a productive choice for extracting information about the representation of plants, their study, fieldwork methodology, and the predominant ideas of nature protection of the time period covered in the text. The book provides predominantly scientific information about the vegetation, both typical plants and rarities of Hiiumaa Island, and about the author's research practices during fieldwork. At the same time, emotional epithets, interjections, metaphoric usage of some concepts ('travelling' plants), indication of one's bodily presence, give a strong individual character to the book that likens it to essayistic prose. It is clear that the notes were taken by a writer holding subjective freedom in esteem. Photographs and the map of the island offer the reader practically useful information, but also add to the aesthetic dimension of the book as a whole. The book fits into the three-part dynamic model of nature writing, thus appearing as a proof of the suitability of the model and of the relevance of an ecocritical approach to this type of work.

\section{ACKNOWLEDGEMENTS}

The article was written with support from the Estonian Science Foundation (grant No. 7790 to Kadri Tüür). The research was supported by the European Union through the European Regional Development Fund (Centre of Excellence CECT).

\section{REFERENCES}

Branch, M. \& Slovic, S. (eds). 2003. The ISLE Reader: Ecocriticism, 1993-2003. University of Georgia Press, Athens and London.

Buell, L. 1995. The Environmental Imagination. Thoreau, Nature Writing and the Formation of American Culture. The Belknap Press of Harvard University Press, Cambridge and London. 
Eilart, J. 1976. Inimene, ökosüsteem ja kultuur. Peatükke looduskaitsest Eestis. Perioodika, Tallinn.

Finch, R. \& Elder, J. 2002. Nature Writing. The Tradition in English. W. W. Norton \& Company, New York and London.

Garrard, G. 2009. Ecocriticism. Routledge, London and New York.

Glotfelty, C. \& Fromm, H. (eds). 1996. The Ecocriticism Reader: Landmarks in Literary Ecology. University of Georgia Press, Athens and London.

Kukk, T. 1999. Eesti taimestik. Teaduste Akadeemia Kirjastus, Tallinn.

Kull, K. 1998. Semiotic ecology: different natures in the semiosphere. Sign Systems Studies, 26, 344-371.

Lotman, K. \& Lepik, I. 2004. Coastal meadow as a habitat. In Coastal Meadow Management. Best Practice Guidelines, pp. 8-25. Ministry of the Environment of the Republic of Estonia, Tallinn.

Love, G. A. 2003. Practical Ecocriticism: Literature, Biology, and the Environment. University of Virginia Press, Charlottesville, Virginia.

Lyon, T. 1996. A taxonomy of nature writing. In The Ecocriticism Reader: Landmarks in Literary Ecology (Glotfelty, C. \& Fromm, H., eds), pp. 276-281. University of Georgia Press, Athens and London.

Maran, T. 2010. An ecosemiotic approach to nature writing. PAN: Philosophy, Activism, Nature, 7, $79-87$.

Murphy, P. D. 2009. Ecocritical Explorations in Literary and Cultural Studies. Lexington Books/ Rowman and Littlefield, Lanham.

Nöth, W. 1996. Ökosemiotik. Zeitschrift für Semiotik, 18, 7-18.

Rebassoo, H.-E. 1967. Hiiumaa floora ja selle genees. Valgus, Tallinn.

Rebassoo, H.-E. 1975a. Botaanilisi kilde 17 Hiiumaa suvest. Valgus, Tallinn.

Rebassoo, H.-E. 1975b. Botaaniliste objektide looduskaitsest Eesti väikestel meresaartel. In Eesti loodusharulduste kaitseks (Kumari, E., ed.), pp. 104-113. Valgus, Tallinn.

Slovic, S. 1996. Nature writing and environmental psychology: the interiority of outdoor experience. In The Ecocriticism Reader: Landmarks in Literary Ecology (Glotfelty, C. \& Fromm, H., eds), pp. 351-370. University of Georgia Press, Athens and London.

Tüür, K. 2004. Nature writing and intersemiosis. In Intertextuality and Intersemiosis (Grishakova, M. \& Lehtimäki, M., eds), pp. 151-167. Tartu Ülikooli Kirjastus, Tartu.

Tüür, K. 2007. Looduskirjanduse määratlus. Acta Semiotica Estica IV, 73-96.

Tüür, K. \& Maran, T. 2005. Eesti looduskirjanduse lugu. In Eesti Looduskultuur (Maran, T. \& Tüür, K., eds), pp. 237-270. Eesti Kirjandusmuuseum, Tartu.

\section{Botaaniline looduskirjandus: kirjandusökoloogiline analüüs}

\section{Kadri Tüür ja Triin Reitalu}

Artiklis on esitatud kirjandusökoloogiline analüüs looduskirjanduse traditsiooni kuuluva Haide-Ene Rebassoo teose "Botaanilisi kilde 17 Hiiumaa suvest" näitel. Looduskirjanduse dünaamilist mudelit on rakendatud kirjandusökoloogilise metodoloogia edasiarendamiseks, aga ka kirjandusökoloogilise lähenemise sobivuse näitamiseks varem alamõtestatud looduskirjandusteoste uurimisel. Analüüsi tulemusena saab järeldada, et allikmaterjal sisaldab nii teaduslikku, ilukirjanduslikku kui ka tarbelist mõõdet; rõhk on taimeteaduslikul teadmisel. 